\title{
OBYEKTIFIKASI KONSEP PERBURUHAN ISLAM DI INDONESIA
}

\author{
Abdul J alil*
}

\begin{abstract}
A bstract: The problem of labor is one of the key issues in the global era that invokes some important questions concerning value, technicality of being human, and the notion of choice. The idea of labor is closely related to the realization of human's potentiality in its multidimensional complexity as well as with social structure and national identity of man. This problem of labor is to do not only with economy, but also with social and political system of a nation. In dealing with labor, there always been a tension between capital-owners, laborers, government and even international political power. As a religion that is said to have made economics its "curriculum", Islam does have an "objectivied" concept of labor represented in a kind of partnership that combines shirkah "inan and ijarah. This partnership necessitates that all parties involved share profit-loss, if any. In this way, no party -be him laborer, capital-owner, or government- is loosing. Moreover, this system offers three advantages, e.g employee-ownership, production-sharing and profit-sharing.
\end{abstract}

Keywords: laborer, Islamic economy

\section{Pendahuluan}

Mendekati agama dengan analisis ilmu-ilmu sosial dikhawatirkan dapat mereduksi makna transendental sebuah agama karena hanya memahaminya sebagai objective term yang observable. Namun, tesis Weber The Protestant Ethic and The Spirit of Capitalism (1904-5) meruntuhkan keraguan tersebut.

Dalam Islam, hubungan agama dan ekonomi diyakini sudah ada sejak awal, bahkan menjadi salah satu pendorong kehadirannya. Kelahiran Islam merefleksikan sebuah reformasi terhadap keangkuhan sistem peradaban masyarakat jabiliyah kala itu. ${ }^{1}$ Keangkuhan ini dapat dilihat dari perlakuan yang tidak fair terhadap perempuan, penindasan terhadap suku dan klan yang kecil, peminggiran kaum miskin, pemusatan kekuasaan pada kaum aristokrat, ketimpangan ekonomi, dan lain-lain. ${ }^{2}$

Dalam kaitannya dengan perdagangan dan industri, Islam sejak awal sangat memperhatikan bidang ini karena Islam pertama-tama dan terutama adalah agama para pedagang, bukan agama

\footnotetext{
*STAIN Kudus, J I. Conge Ngembalrejo PO Box 51 Kudus, e-mail: djalil_elquds@ yahoo.com, telepon: 081325250907. ${ }^{1}$ Term 'jabiliyłah' menunjuk pada era kehidupan kabilah-kabilah Arā̄ sebelum RasulæAllab diangkat menjadi Rasul, yang ditandai dengan ketiadaan petunjuk Allah swt., seorang Rasul Penerima wahyu, tidak ada pula kitab suci yang menjadi pedoman hidup. Philip K. Hitti, History of The Arabs (London: The Macmillan Press Ltd, 1970), 87.

${ }^{2}$ Fazlur Rahman menyebutkan bahwa problem akut yang dihadapi masyarakat Arab pada waktu itu, sebagaimana tampak dalam surat-surat awal al-Q ur'an adalah pholiteisme (penyembahan berhala), eksploitasi kaum miskin, permainan kotor dalam perdagangan dan ketiadaan tanggung jawab umum terhadap masyarakat. Problem aktual lain yang juga menjadi ciri kehidupan waktu itu adalah perpecahan dan kecenderungan konflik antar kabilah, sehingga mudah sekali berubah menjadi perang yang berkepanjangan. Salah satu contohnya adalah Perang Basus yang berlangsung 40 tahun antara Bani Bakr dan Taghlib yang hanya disebabkan oleh kematian seekor unta. Fazlur Rahman, Islam and Modernity Transformation of an Intellectual Tradition (Chicago: The University of Chicago Press,1982), 3; Abural-Faraj al-Isfihani>K itab al-Aghani,-vol. 1 (Beirut: Matha'at al-'Arabiyah, t.t.), 140-152.
} 
gurun pasir serta bukan pula agama para petani. ${ }^{3}$ Kondisi geografis daerah $\mathrm{H}$ ijazyang terletak di antara tiga benua, yaitu Asia, Eropa, dan Afrika memberi keuntungan tersendiri karena dilalui rute perdagangan antara Persia dan Roma serta daerah jajahannya seperti Sham (Shria), Etiopia dan Yaman. Ditambah lagi, rute perdagangan Roma dan India selalu melewati bagian selatan dan timur Arabia selama berabad-abad, dan selanjutnya disebut Rute Perdagangan Selatan. Para kafilah dagang memperoleh keuntungan dari timbulnya pasar-pasar musiman yang ada di daerah Yaman, Hijaz, dan Sham terutama di San'ałıbukota Yaman), Yathrib dan Makkah, dan mendapatkan barang-barang dagangan. Sementara rute dagang yang melewati bagian utara Arabia juga sangat signifikan. Komoditas dari India dibawa menggunakan kapal laut menuju O man, kemudian dibawa lagi melalui jalan darat melintasi bagian utara Arabia dan Syam dan kemudian ke Roma. Sepanjang rute ini pasar-pasar musiman didirikan bergantung pada aktivitas perdagangannya. ${ }^{4}$

Di era modern, Islam diharapkan mampu berbicara banyak mengenai konsep industri melalui penelusuran norma-norma Islam, baik dalam bentuk prinsip dasar maupun operasional, baik yang terdapat dalam teks-teks nas\}s\} mapun pengalaman historis masyarakat Islam, agar penanganan masalah industri tetap mengacu kepada fitrah kemanusiaan yang menjadi misi setiap agama. Persoalan utama yang harus segera diselesaikan adalah menjawab problem scarcity sebagai akibat ketidakseimbangan antara kebutuhan masyarakat dengan faktor-faktor produksi yang tersedia (sumber daya, modal, tenaga kerja dan manajemen). Kebutuhan dasar manusia terbentang dari kebutuhan yang sifatnya individual (private goods) seperti sandang, pangan dan papan, dan kebutuhan publik (public goods) seperti pendidikan, kesehatan dan ilmu pengetahuan dan teknologi. Dua bentuk kebutuhan tersebut merupakan sarana kehidupan yang tak terelakkan. Untuk memastikan keseimbangan dua kebutuhan tersebut, penggunaan dan penguasaan serta faktor-faktor produksi, serta proses produksi harus berada dalam kerangka keadilan.

\section{J angkar Perburuhan Indonesia}

Sejarah perburuhan di Indonesia dimulai dengan fenomena perbudakan. Para budak merupakan "buruh" pada zaman itu. 'U pah' yang mereka terima adalah makanan, pakaian dan perumahan. U pah berupa uang biasanya tidak diberikan kepada mereka. O rang lain atau badan

\footnotetext{
${ }^{3}$ Pendapat bahwa monoteisme Islam yang kuat sangat berkaitan dengan pengalaman ketidakberartian manusia (mans experience of his own insignificance) di tengah kegersangan gurun pasir, telah dipopulerkan pada abad ke 19 Ernest Renan serta sarjana-sarjana lainnya. Namun demikian, pendapat tersebut sebenarnya sama sekali tidak didasarkan kepada fakta yang memadai. Orang-orang yang pertama kali menjadi Muslim bukanlah orang-orang badui yang hidup di gurun pasir, melainkan orang-orang berasal dari pusat perdagangan di Mekkah dan tanah pertanian di Madinah. Tetapi memang benar kalau dinyatakan bahwa sumberdaya manusia bagi kepentingan ekspansi orang-orang Arab terutama berasal dari gurun ini; dan barangkali bisa juga dikatakan bahwa moralitas Islam telah bercampur-baur dengan nilai-nilai utama yang hidup di gurun pasir, kendati dalam bentuknya yang telah disesuaikan dengan kehidupan kota. Gurun pasir juga menjadi sarana penyeberangan lewat mana para pedagang Makkah melakukan kegiatan-kegiatan perdagangan mereka, sebagaimana laut menjadi sarana kegiatan perdagangan pedagang dari Venesia dan wilayah Italia lainnya. Di sisi lainnya, orang-orang Badui jarang menjadi Muslim yang taat, baik pada masa Nabi Muhammad maupun masa belakangan. W. Montgomerry Watt, Islam dan Peradaban Dunia, ter. Hendro Prasetyo (J akarta: Gramedia, 1997), 23.

${ }^{4}$ Patricia Crone, Meccan Trade and The Rice of Islam (N ew J ersey: Princeton University Press, 1987), 30.
} 
itu merupakan "majikan" yang berkuasa penuh dan mutlak, bahkan menguasai pula hidupmati para budak itu. ${ }^{5}$

Hubungan industrial yang kapitalistik mulai terbentuk pada tahun 1930-an ketika terjadi peralihan status dari budak menjadi buruh yang ditandai dengan adanya produksi komoditas internasional secara massal (generalized commodity production). ${ }^{6}$

Pada masa awal kemerdekaan, hubungan industrial nampak diwarnai oleh pergolakan politik. Pada masa awal kemerdekaan hubungan industrial relatif berjalan baik. Serikat-serikat pekerja mempunyai peranan penting dalam bidang ekonomi, pemerintahan dan kegiatankegiatan politik praktis. Para anggotanya memandang bahwa organisasinya dapat dipakai sebagai alat (vehicle) untuk memperjuangkan kepentingan mereka. ${ }^{7}$

Pada masa awal pemerintahan Orde Baru, pemerintahan berhasil membentuk MPBI (Majelis Permusyawaratan Buruh Indonesia) yang diarahkan untuk membicarakan berbagai hal untuk mengkonsolidasi kehidupan serikat buruh. Pada tahun 1972, dua puluh satu serikat buruh disatukan sehingga melahirkan Federasi Buruh Seluruh Indonesia (FBSI). Dalam perjalanannya, federasi ini dinilai tidak demokratis. ${ }^{8}$

Tahun 1974, pemerintah bersama komponen masyarakat lainnya merumuskan apa yang disebut dengan HIP (H ubungan Industrial Pancasila). Melalui konsep ini, diharapkan agar sistem hubungan industrial di Indonesia berjalan sesuai budaya bangsa yang tercermin dalam UUD 45 dan Pancasila. Dalam perkembangannya, konsep ini memang telah melahirkan praktekpraktek hubungan industrial yang mantap dan serasi. Akan tetapi, dari sisi pekerja, hubungan ini belum menghasilkan manfaat optimal yang bisa dirasakan oleh mereka. Partnership sebagaimana yang diharapkan antara pengusaha dengan pekerja ternyata belum berjalan dengan baik.

Memang, Upah Minimum Regional (UMR), yang kemudian berubah menjadi Upah Minimum Propinsi (UMP) dan Upah Minimum Kabupaten (UMK), terus mengalami kenaikan sesuai dengan perkembangan daya beli masyarakat. Namun, persentase kenaikan UMR tersebut

\footnotetext{
${ }^{5}$ Imam Soepomo, Hukum Perburuhan Bidang Hubungan Kerja (J akarta: Djambatan, 1987), 10.

${ }^{6}$ ntuk mendukung produksi, intitusi keuangan didirikan oleh Willem Daendels, yang sangat mengagumi revolusi Perancis. Ada dua lembaga keuangan yang didirikan, yakni Nederlansche Handels Maatschapij (NHM) dan J avasche Bank. Kehadiran kedua lembaga juga dimaksudkan untuk menghambat arus perdagangan Inggris di Pulau J awa, karena saat Inggris sudah memiliki 100 kapal yang berlabuh di Batavia, sementara B elanda hanya memiliki 43 buah. Polak, "Tentang Cultuurstelsel dan Penggantiannja", dalam Penelitian Sedjarah, no 4, th. II (September 1961), 18; Edi Cahyono, Pekalongan 1830-1870: Transformasi Petani Menjadi B uruh Industri Perkebunan (Bandung: LEC, 2001).

${ }^{7}$ Fenomena tersebut tampak, misalnya, dari berdirinya beberapa serikat buruh. Yang berhaluan kiri berdiri Partai B uruh Indonesia (PBI), Partai Rakyat Sosialis (PRS), yang akhirnya melebur diri menjadi Barisan Buruh Indonesia (BBI). Di kalangan buruh perempuan, muncul Barisan Buruh Wanita (BBW) yang akhirnya berganti nama menjadi Gabungan Serikat Buruh Indonesia (GABSI) setelah kongres di Madiun tahun 1946. Organisasi buruh juga muncul berdasarkan jenis pekerjaan mereka. Misalnya muncul Serikat Buruh Perkebunan Indonesia (SARBUPRI) dan Serikat Buruh Rokok Kudus. Pada 29 November 1946, seluruh serikat buruh membentuk serikat gabungan yang bernama Sentral Organisasi Buruh Seluruh Indonesia (SOBSI). Pada 1950, organisasi ini beranggotakan 2,5 juta orang yang terdiri dari 34 serikat buruh. Data lebih dalam dapat ditelusuri dalam tulisan Lance Castle, Tingkah Laku Agama, Politik dan Ekonomi di J awa: Industri Rokok Kudus (Yogjakarta: Sinar Harapan, 1982), 133; Suri Suroto, "Gerakan Buruh dan Permasalahannya", dalam Prisma, no. 11 th. 1981, 11.

${ }^{8}$ Sutanto, "Prospektif Tenaga Kerja dalam Hubungan Industrial sesuai dengan UU Nomor 13 tahun 2003". Makalah ini disampaikan dalam Kongres Sarjana Ekonomi Indonesia XV, Batu, Malang, 13-15 J uli 2003, 3.
} 
tidak memiliki korelasi kuat dengan peningkatan kebutuhan buruh dan masyarakat. Itu berarti tingkat kesejahteraan buruh masih dibawah standar. $\mathrm{H}$ al ini yang membuat eskalasi tuntutan dan demontrasi semakin meningkat khususnya yang dilancarkan oleh pekerja. ${ }^{9}$

Di era reformasi, yang didahului dengan perpindahan kekuasaan dalam pemerintahan, serikat buruh tumbuh dengan subur sesuai dengan aspirasi dan tuntutan terhadap pembebasan. $\mathrm{H}$ al tersebut merupakan konsekuensi diratifikasinya Konvensi ILO tahun 1948 tentang Kebebasan Berserikat dan Perlindungan Berorganisasi. ${ }^{10}$

Namun di pihak perusahaan, para pengusaha tidak dapat segera memenuhi standar perburuhan yang baru, disamping karena pertumbuhan ekonomi yang rendah, juga karena mereka menghadapi sejumlah pilihan sulit, terutama berkaitan dengan pengeluaran sejumlah biaya 'siluman', yang tidak berhubungan dengan proses produksi. Selain itu, persediaan tenaga kerja yang berlimpah juga menjadi salah satu pertimbangan pengusaha untuk tidak segera merespons tuntutan pekerja yang ada. Oleh karena itu, sangat dimengerti jika buruh selalu menuntut perbaikan nasib. ${ }^{11}$

Untuk keluar dari situasi ini, banyak negara, termasuk Indonesia, kemudian mengadopsi konsep negara sejahtera (welfare state), yang sesungguhnya lahir sebagai respons atas depresi ekonomi 1935 dan Perang Dunia II. ${ }^{12}$ Landasan filosofisnya berbeda dengan Darwinisme Sosial tentang kapitalisme laissez-faire. Negara sejahtera berkeyakinan bahwa kesejahteraan individu merupakan sesuatu yang sangat penting dan tidak mungkin hanya tergantung dengan operasi pasar. Paradigma filsosofis ini mengindikasikan pengakuan formal terhadap ekonomi mainstream yang menyatakan bahwa kemiskinan dan ketidakmampuan seseorang dalam memenuhi kebutuhannya bukanlah dalil atas kegagalannya. Para pekerja yang terpaksa melakoni pekerjaan dengan gaji di bawah UMR dan UMK, para pengangguran dan mereka yang jatuh miskin tidak semata-mata disebabkan oleh kesalahannya sendiri. O leh karena itu, perlu dicarikan cara agar mereka mendapatkan pelayanan umum seperti kesehatan, pendidikan, transportasi, perumahan, dan lain-lain, disamping juga melindunginya dari resiko sosial, ekses industrialisasi, ketidakmampuan dan pengangguran.

Negara sejahtera tidak perlu mengajukan perubahan fundamental untuk merealisasikan tujuannya. Peran negara yang lebih besar sudah dianggap cukup untuk menjalankan fungsi pasar secara sempurna dan memperbaiki ketidakadilan yang diciptakan kapitalisme laissez-faire. Secara teori, target ini bisa dilaksanakan melalui enam langkah: regulasi, nasionalisasi, gerakan buruh, kebijakan fiskal, pertumbuhan yang tinggi, dan full employment. Enam langkah tersebut di atas pada dasarnya mengakui adanya full employment, distribusi kekeyaan dan pendapatan

\footnotetext{
${ }_{9}^{9}$ Muhaimin Iskandar, Membajak di Ladang Mesin (Semarang: Yawas, 2004), 84.

${ }^{10}$ Berkaitan dengan ratifikasi itu, pada 18 J uni 1998, ILO mendeklarasikan prinsip-prinsip dan hak-hak mendasar di tempat kerja. Deklarasi ini merupakan tonggak sejarah baru bagi ILO untuk mengubah persepsi yang berkembang, seolah-olah ILO hanya mendukung kepentingan negara maju, sekaligus merupakan jawaban terhadap tantangan globalisasi pasar kerja dan perdagangan yang telah menjadi fokus perdebatan internasional. Deklarasi ILO tersebut bertujuan merekonsiliasi keinginan semua pihak dalam hubungan industrial, menggairahkan usaha-usaha nasional seiring dengan kemajuan sosial-ekonomi, mengakomodir perbedaan kondisi lokal masing-masing negara, dan untuk menegakkan Hak Asasi Manusia (HAM).

${ }^{11}$ Tempo interaktif, 19 J anuari 2005.

${ }^{12}$ Asa Briggs, "The Walfare State in Historical Perspective", dalam Archives Europeenes de Sociologie, 1961.
} 
secara adil sebagai bagian dari tujuan pokok kebijakan negara. Filosofi ini menuntut peranan negara dalam bidang ekonomi menjadi lebih aktif dibanding dengan paham kapitalisme laissezfaire, atau bahkan teori Keynes.

H anya saja, karena konsep negara sejahtera berbicara tentang sesuatu yang abstrak, yakni kesejahteraan, maka sampai hari ini para pakar belum mampu menyepakati definisi negara sejahtera. Bahkan Titmuss sampai berkesimpulan bahwa negara sejahtera adalah abstraksi yang tidak bisa didefinisikan. Dengan demikian, banyak dijumpai contoh praktis yang berbeda antara satu negara dengan lainnya, mulai dari yang kurang sempurna seperti Amerika Serikat, sampai yang sempurna seperti Swedia.

Sekalipun negara sejahtera telah berusaha semaksimal mungkin mengusung kesejahteraan umum, namun tetap saja tidak bisa lepas dari unsur kapitalisme. la tidak bisa keluar dari unsur filsafat enlightenment ${ }^{13}$ atau dari keyakinan akan kesucian sistem pasar. Sikap antagonistik enlightenment terhadap pertimbangan nilai juga tetap tak berkurang. Karena itu, pendekatan yang dipakai adalah pasar bebas. Negara tidak perlu mencampuri urusan impor tenaga kerja asing, misalnya, asal dilakukan sesuai mekanisme pasar, fair, tidak ada rekayasa dan permainan kotor.

Dalam kondisi ini, negara diibaratkan sebagai wasit dalam permainan sepak bola. la tidak mempunyai hak menendang atau memegang bola. Yang perlu dilakukan adalah agar permainan dalam sepak bola tersebut berjalan lancar dan tidak ada kecurangan. ${ }^{14}$

Teori pasar di atas, ternyata menimbulkan banyak ekses. Mereka yang mempunyai kapital tinggi akan dengan sendirinya menguasai pasar, sehingga potensial melakukan penyimpangan dan ketidakadilan, sehingga apa yang disebut sebagai kesejahteraan (walfare) masih jauh panggang dari api.

Kebenaran pernyataan ini tidak membutuhkan riset yang njlimet karena sejak dulu kita memang belum bisa menyelesaikan kondisi ketenagakerjaan. Dari dulu masalah perburuhan menjadi sorotan banyak pihak, tapi dari dulu pula masalah ini tidak selesai. Hal ini karena ketidakseimbangan supplay dan demand tenaga kerja. Teorinya memang benar bahwa slope upah bergerak positif sesuai dengan perkembangan permintaan, tapi ternyata pergerakannya tidak secepat yang diharapkan sehingga terjadi kesenjangan (baca: pengangguran). ${ }^{15}$

\footnotetext{
${ }^{13}$ Istilah enlightenment (pencerahan) seringkali disebut juga dengan the age of reason (era akal) yang merupakan antitesa terhadap banyak doktrin gereja yang anti ilmu pengetahuan. Crane Brinton, "Eglightenment", dalam Encyclopedia of Philosophy, vol 2 (New York: Macmillan and the Free Press, 1967), 521.

${ }^{14}$ Umer Capra, Islam dan Tantangan Ekonomi (J akarta: IIT, 2000), 271-278.

${ }^{15}$ Secara teoritis, kepentingan buruh dan majikan akan terselesaikan oleh adanya mekanisme pasar yang mempertemukan supplay dan demand dalam sebuah equilibrium pasar. Kurva permintaan ini bisa bergeser ke kiri atau ke kanan. J ika bergeser ke kanan berarti ada permintaan jumlah tenaga kerja. Kalau penawaran tidak berubah, maka akan terjadi kenaikan penyerapan tenaga kerja. Tapi, jika kurva bergerak ke kiri, maka berarti ada penurunan permintaan. J ika penawaran harga tidak berubah, maka akan ada penurunan volume penyerapan tenaga kerja. Namun, teori ini tidak selamanya demikian. Di dalamnya ada beberapa pengecualian seperti terlihat pada: pertama, kasus Constans Cost Supplay dimana kenaikan produksi tidak mengakibatkan kenaikan harga, kedua, kurva penawaran inelastis sempurna dimana kenaikan permintaan hanya akan berakibat pada kenaikan harga barang tanpa diikuti kenaikan volume transaksi penjualan dipasar, ketiga, Backward B ending Supplay dimana kurva penawaran mempunyai slope negatif, dan keempat, kasus Decreasing Cost Supplay dimana kenaikan proses produksi justru menurunkan ongkos produksi per-unit. Budiono, Tori Eknomi Mikro (Yogyakarta: BPFE, 1998), 4552; William A. McEachern, Ekonomi M ikro Pendekatan Kontemporer (J akarta: Thomson Learning, 2001).
} 
Karena ketidakseimbangan supplay dan demand itulah, maka harga (upah) tenaga kerja di Indonesia sangat murah. Upah buruh ditetapkan dengan UMP dan UMK hanya untuk memenuhi Kebutuhan Hidup Minimal (KHM), bukan pada Kebutuhan Hidup Layak (KHL), ${ }^{16}$ sehingga seluruh potensinya habis untuk opportunity cost, tanpa pernah bisa menikmati economic rent. Kenyataan ini menunjukkan bahwa di Indonesia faktor yang paling mempengaruhi pasar tenaga kerja masih upah, belum bergeser ke faktor selera, nilai pengalaman, atau faktor non materiil lainnya. ${ }^{17}$

Oleh karena itu, sangat dimengerti jika buruh selalu menuntut perbaikan nasib. Tahun 2004 ada 103 kasus pemogokan yang melibatkan 44.280 tenaga kerja, sehingga menyebabkan hilangnya jam kerja sebanyak 462.624 jam. ${ }^{18}$

Data diatas merupakan fakta tak terbantahkan bahwa posisi buruh memang sangat sulit. Kaum buruh terus hidup dengan kesadaran tradisional, sementara mereka di hadapkan secara langsung dengan praktek-praktek diskursif dan hegemonisasi modal.

\section{Tawaran Islam}

Untuk meneropong isu buruh dan kompleksitas persoalannya, mau tidak mau kita mesti

\footnotetext{
${ }^{16}$ Teori yang melandasi besaran upah tersebut antara lain adalah: a) Teori Subsistensi yang digunakan untuk pekerja yang tidak mempunyai keterampilan khusus. Upah, menurut teori ini, didasarkan pada tingkat subsistensi sesuai tingkat kebutuhan mendasar; b) Teori Dana Upah. Menurut terori ini, upah pekerja adalah bagian dari modal untuk berproduksi. Besaran upah pekerja akan selalu didasarkan pada penambahan modal atau pengurangan jumlah pekerja; c) Teori Marginal Productivity. Menurut teori ini, upah tenaga kerja didasarkan pada permintaan dan penawaran tenaga kerja. Pengusaha akan menambah upah pekerja sampai batas pertambahan produktivitas marjinal minimal sama dengan upah yang diberikan pada mereka; d) Teori B argaining. Teori ini mengandaikan ada batas minimal dan maksimal upah. U pah yang ada merupakan hasil persetujuan kedua belah pihak; e) Teori Daya B eli. Teori ini mendasarkan permintaan pasar atas barang dengan upah. Agar barang terbeli, maka upah harus tinggi. J ika upah rendah, maka daya beli tidak ada, dan barang tidak laku. J ika hal ini dibiarkan, maka akan terjadi pengangguran besar-besaran; f) Teori upah hukum alam. Teori ini menyatakan bahwa upah ditetapkan atas dasar biaya yang diperlukan untuk memelihara atau memulihkan tenaga buruh yang telah dipakai untuk berproduksi. B ambang Setiadji, U pah antar Buruh Industri di Indonesia (Surakarta: Muhammdiyyah University Press, 2002),21; Mamik Indaryani, et. al. "Hasil Penelitian Penentuan Upah Minimal di Kabupaten Kudus J awa tengah" (Kudus: Kantor Tenaga Kerja dan Transmigrasi bekerja sama dengan Litbang UMK, 2002).

${ }^{17}$ Faktor-faktor non upah yang mempengaruhi penawaran tenaga kerja adalah; a) Sumber Pendapatan Lain. Meskipun beberapa pekerjaan memberikan berbagai bentuk imabalan non keuangan, namun alasan utama orang bekerja adalah mencari uang. Dengan demikian, maka tawaran tenaga kerja sesungguhnya berhubungan dengan sumber pendapatan lain yang ia miliki. Mahasiswa yang mendapat beasiswa, biasanya menawarkan waktu bekerja lebih pendek dibandingkan dengan yang mandiri; b) Faktor non Keuangan. Tenaga kerja adalah sumber daya yang khusus. la tidak sama dengan modal dan tanah yang dapat ditawarkan dengan seenaknya tanpa melihat lokasi dan pemiliknya. Karena pekerjaan mensyaratkan keterlibatan person secara langsung, maka faktor non keuangan semisal tingkat kesulitan pekerjaan, lokasi, kualitas lingkungan pekerjaan, dll., akan memainkan peranan penting dalam penawaran tenaga kerja; c) Pengalaman Kerja. Hal lain yang juga menentukan penawaran adalah nilai pengalaman. Mahasiswa jurusan manajemen keuangan akan lebih senang bekerja sebagai asisten bendahara dalam sebuah micro finance dari pada bekerja menjadi penjual kacang goreng. Seorang calon pengacara lebih senang kerja sebagai asisten hakim dari pada pekerjaan lain karena ada nilai pengalaman yang akan dipetik nantinya. Bahkan beberapa orang rela menerima bayaran yang relatif rendah, dengan harapan nantinya mendapatkan bayaran yang lebih tinggi; [4] Selera Pekerja. Sebagaimana selera terhadap barang berbeda, maka selera pemilik sumber daya terhadap sebuah pekerjaan juga berbeda. Karena itulah, sebagian orang lebih senag bekerja di lapangan, sementara yang lain lebih suka bekerja di balik meja. Sebagian orang jijik terhadap darah, sementara yang lain memilih kerja sebagai perawat. Begitulah seterusnya. Semua ini akan mempengaruhi penawaran kerja. William A. McEachern, Ekonomi Mikro Pendekatan Kontemporer (J akarta: Thomson Learning, 2001), 222-223.
}

${ }^{18}$ Tempo interaktif, 19 J anuari 2005. 
melangkah ke persoalan yang lebih mendasar, yaitu paradigma perekonomian dalam Islam, ${ }^{19}$ untuk menentukan arah dan alokasi sumber daya, modal, peningkatan produksi dan hak buruh terhadap surplus value.

Berbicara tentang pemerataan sumber daya, Khalifah Umar pernah melakukan nasionalisasi lahan-lahan golongan feodal dan mendistribusikannya pada kalangan miskin. ${ }^{20}$ Dari sini dapat dipahami bahwa pandangan Islam adalah membatasi hak milik pribadi dan mengalokasikannya secara merata untuk kemakmuran rakyatnya.

Pola membatasan hak milik seperti di atas bisa jadi tidak hanya berlaku bagi kepemilikan lahan, tetapi dalam konteks yang lebih makro seharusnya juga berlaku bagi penguasaan modal. Walaupun tidak ada nash yang secara tegas tentang pembatasan ini, akan tetapi Islam membatasi kekayaan individu dengan zakat. A pabila seseorang mempunyai emas atau uang yang tersimpan, orang itu terkena zakat $2,5 \%$. Artinya dalam jangka 40 tahun sebenarnya kekayaannya itu sudah habis karena setiap tahun kekayaannya diambil 2,5\%.

Ini artinya bahwa posisi produktivitas modal merupakan prinsip yang tidak bisa ditawar. Dan ketika modal diputar, dari sanalah hubungan antara buruh dan majikan terbangun. H ubungan ini, secara normatif, terakomodir dalam konsep ijakah yang berpilar pada kesepakan mereka tentang berapa upah, sebagaimana tampak dalam definisinya: "aqd 'alałmanfa'ah aw 'amal bi ajr aw 'iwad/ma'lum. Istilah 'aqd di sini mempunyai pengertian adanya kesepakatan kedua belah pihak (ajis dan musta'jir) dengan hak dan dalam posisi yang sama. ${ }^{21}$

\footnotetext{
${ }^{19}$ Basis paradigmatik ekonomi Islam adalah ketercukupan makhluk akan kebutuhannya, sebagaimana tampak dalam firman:

Data menunjukkan baḱẃá kekayaan alam yang disediakan Tuhan di bumi ini sebenarnya sangat mencukupi untuk sekedar memenuhi kebutuhan (bedakan dengan: keinginan) makhluk hidup yang melata di atasnya, tidak terkecuali umat manusia. Lebih-lebih dengan senjata ilmu dan teknologinya, umat manusia kini mampu mengeksplorasi kekayaan alam yang tersimpan di perut bumi yang paling dalam sekalipun. Oleh sebab itu, apabila dalam kenyataannya, banyak orang yang tidak mampu memenuhi kebutuhan dæærûri-^ya, apalagi yang takmîliatau tahsîni, itulah bukan karena persoalan supply yang terbatas melainkan lebih karena distribusi yang terampas. Berdasar cara pandang ini, IImu Ekonomi Islam sering didefinisikan sebagai ilmu yang mempelajari tata kehidupan kemasyarakatan dalam memenuhi kebutuhannya untuk mencapai ridla Allah. Ta'rif ini setidaknya telah mengakomodir tiga domain utama; a) domain tata kehidupan, b) domain pemenuhan kebutuhan, dan c) domain ridla Allah.

${ }^{20}$ Kasus ini bermula ketika 'U mar menjadi Khalifah, sebagian orang berlebihan dalam memiliki tanah. Mereka membuat batas-batas tanah dengan memasang batu-batu dan pagar di atas tanah tersebut untuk mencegah orang lain memilikinya, namun mereka sendiri tidak memanfaatkan tanah tersebut sehingga tidak terawat selama bertahuntahun. $\mathrm{H}$ al ini jelas bertentangan dengan maksud Rasulullah ketika membolehkan Ihya'>al-M awat. Sebab tujuan dari aktifitas ini adalah mendorong produktivitas tanah, baik untuk mengembangkan sektor pertanian maupun sektor-sektor perekonomian yang lain, seperti pembangunan fasilitas pemukiman maupun perdagangan. Dalam hal ini U mar memberikan batasan waktu tiga tahun kepada pemiliknya untuk segera mengelola tanahnya, namun jika lebih dari tiga tahun tanah tersebut tidak dikelola, maka pemiliknya dinyatakan tidak berhak lagi, dan U mar tidak segan-segan mengambil alih tanah tersebut sebagaimana yang terjadi dalam kasus Bilabal-H \$ith al-Muzni>kemudian menyerahkan tanah itu kepada orang lain yang mampu mengelolanya. Bilabal-M uzni mempunyai tanah luas pemberian Rasulullah, tapi dia tidak dapat menggarap seluruhnya. Kemudian Umar-pun berkata kepadanya: "Rasulullah tidak memberikan lembah itu kepadamu untuk kamu pagari agar orang-orang tidak bisa mengambilnya, akan tetapi beliau memberikan kepadamu agar kamu menggarapnya. Oleh karena itu, ambillah dari tanah tersebut yang sanggup kamu kelola dan yang lainnya kamu kembalikan". Selanjutnya 'Umar membagi-bagikan tanah tersebut kepada kaum Muslimin. S.M. Hasanuz Zaman, Economic Foundation of an Economic State: The Early Experience (Leicester: The Islamic Foundation, 1991), 125.

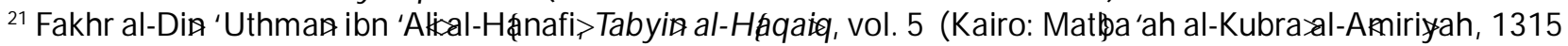

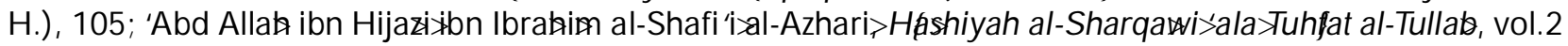


J ika kapitalisme cenderung merampas surplus value, ${ }^{22}$ maka dalam Islam keuntungan produksi dibagi secara adil antara buruh dan majikan. Dalam surat an-Nahl ayat 71 disebutkan:

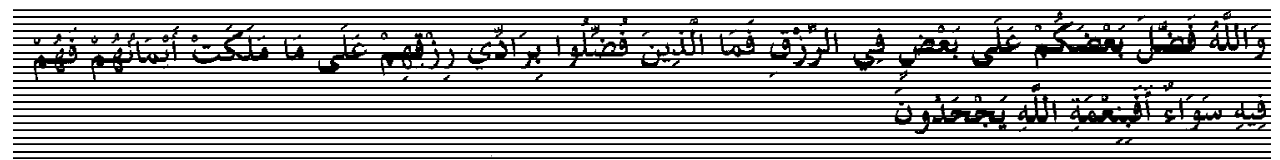

“Dan Allah melebihkan sebahagian kamu dari sebahagian yang lain dalam hal rezki, tetapi orang-orang yang dilebihkan (rezkinya itu) tidak mau memberikan rezki mereka kepada budak-budak yang mereka miliki, agar mereka sama (merasakan) rezki itu. Maka mengapa mereka mengingkari ni mat Allah?"

Dengan pemaknaan kontekstual bahwa kata aymanuhum (budak) di ditafsiri sebagai buruh yang bekerja pada majikan, maka konsep idealnya adalah ada pengembalian surplus value kepada mereka. Disamping itu, para pekerja yang terlibat dalam proses produksi juga harus menikmati hasilnya. Nabi bersabda:

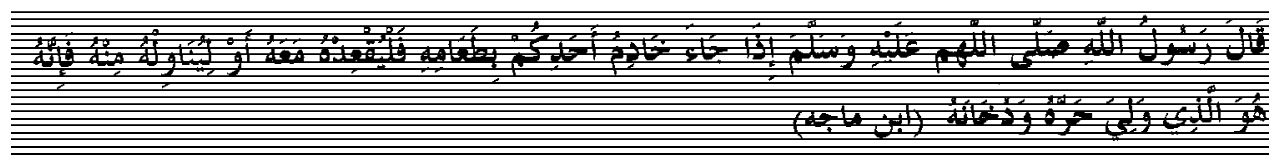

"Rasulullah bersabda: Ketika buruhmu datang dengan membawa makanan (laba usaha, penj), maka ajaklah duduk bersamamu dan ambilkan sebagiannya, sebab dialah yang merasakan suka-dukanya"

Secara filosofis, ketentuan Islam tentang distribusi kekayaan ini sebenarnya sangat radikal. $\mathrm{H}$ anya saja yang menjadi persoalan adalah siapa yang mempunyai otoritas untuk mengambil kelebihan kekayaan dari si kaya itu? A pakah si buruh sendiri yang akan mengambilnya secara paksa atau melalui perantara negara, yang dalam hal ini negara berfungsi sebagai Robin Hood bagi si miskin. Nabi sendiri pernah menginstruksikan kepada Mu'adz ketika diangkat sebagai gubernur agar mengambil harta orang-orang kaya dan mendistribusikannya untuk kepentingan bersama. Dalam konteks inilah Abu§har al-G hifariænengatakan: "Saya heran terhadap mereka yang tidak kuat makan, mengapa tidak (memperbaharui nasib dengan) menghunus pedang?" 23

Masalahnya kemudian adalah karena buruh sudah menjadi kelas atau komunitas tersendiri, maka rumusan-rumusan hukum tekstual yang telah dihasilkan oleh ulama terdahulu kurang mampu mengakomodir isu perburuhan kontemporer. Persoalan buruh dewasa ini sudah menjadi masalah sosial yang sangat kompleks yang melibatkan institusi dan struktur-struktur negara. Maka mengkaji isu buruh harus pula melibatkan pendekatan sosial, ekonomi dan politik.

Karena itu, konsep ijakah ini perlu dikombinasikan dengan shirkah 'inaß. Sebagaimana diketahui, bahwa shirkah 'inaß adalah kontrak kerja sama antara dua orang atau lebih untuk melaksanakan sebuah pekerjaan. Setiap pihak memberikan suatu porsi dari keseluruhan dana,

(Beirut: Dasal-Ma'rifah, t.t.), 83; Muhł̧mmad al-Khatijb al-Sharbini>M ughni al-Muhtaj; vol. 2 (Kairo: MustłfaralBab al-H alibi> 1985), 332; Mansł⿺ b. Yunus b. Idris al-Buhuti>S Sharh/M untaha al-Iradat al-Musamma, vol. 2 (Madinah: Maktabat al-Salafiyah, t.t.), 350.

${ }^{22}$ Teori ini kemukakan oleh Karl Marx. Menurutnya, nilai suatu barang merupakan penjumlahan dari tenaga kerja yang digunakan untuk memperoduksinya. Dengan demikian, apa yang disebut kapital atau modal pada hakikatnya meru[akan tenaga buruh yang dibekukan. Mannan, Islamic E conomy, 88.

${ }^{23}$ Shawqial-Fanjari>H uququal-'U mmal fi al-Islam (Riyad: Rabitatt al-'Alam al-Islami>1980), 36. 
dan juga berpartisipasi dalam kerja. Kedua belah pihak berbagi dalam untung maupun rugi (profit-loss sharing) sesuai dengan kesepakatan yang mereka capai. ${ }^{24}$

Dengan kombinasi shirkah 'inan-ijakah, seorang buruh mempunyai posisi yang relatif sama dengan majikan dalam hal keuntungan. Semakin tinggi laba yang diperoleh, maka dengan sendirinya upah mereka akan naik. Begitupun sebaliknya. J ika perusahaan mengalami kerugian, maka seorang buruh-pun ikut merasakan derita majikannya.

Aplikasi teori shirkah ini dapat menggunakan gainsharing approach sebagaimana telah dilakukan oleh Manajemen Sumber Daya Modern. Gainsharing adalah pendekatan kompensasi yang berhubungan dengan outcome tertentu. Sistem ini diset up sebagai bentuk berbagi keuntungan dengan pekerja atas performa dan produktvitas mereka dalam menghasilkan peningkatan laba dalam perusahaan. Biasanya gainsharing diterapakan terhadap seluruh pekerja, bukan secara individual. ${ }^{25}$

Gainsharing dibagi manjadi tiga kategori, yaitu; kepemilikan pekerja, sharing produksi, dan sharing keuntungan.

\section{Employee ownership}

Employee ownership adalah pendekatan gainsharing bagi pekerja untuk memiliki perusahaan. Beberapa perusahaan memperbolehkan pekerja membeli sahamnya sebagai andil perusahaan. Hasilnya adalah partisipasi pekerja dalam memiliki bagian-bagian perusahaan.

Pendekatan revolusioner ini salah satunya diwujudkan dengan rencana kepemilikan saham pekerja, atau ESOP (Employee S tock O wnership Plan). Sekalipun employee ownership dilakukan dengan berbagai cara, namun semua berarti pekerja membeli saham perusahaan. Ada beberapa model ESOP yang bisa dipilih perusahaan, antara lain adalah:

a. Pekerja membeli saham dengan uang pinjaman berdasarkan perjanjian pekerja.

b. Pekerja membeli saham dengan dana dari kontribusi pajak (tax-deductible contribution).

c. Pekerja membeli saham melalui keuntungan yang akan diperoleh di perusahaan dengan perencanaan tertentu.

d. Pekerja membeli saham melalui perusahaan yang sudah go public.

Dengan cara tesebut, ESOP sesungguhnya dapat digunakan untuk melindungi perusahaan dari serangan kerjasama (corporate raider), perburuan membeli perusahaan, pemogokan buruh. ESOP juga bisa menjadi salah satu cara untuk malakukan divestasi perusahaan menuju prospek yang lebih cerah.

2. Production sharing plans

Production sharing plans adalah rencana pembagian produksi dengan pekerja dengan memberikan bonus ketika melebihi tingkat output yang direncanakan. Rencana ini cenderung menjadi jangka pendek dan berhubungan dengan tujuan produksi yang spesifik.

\footnotetext{
${ }^{24}$ Wahbah Zuhąyli> al-Fiqh al-Islami wa Adillatuh, vol. 5 (Damaskus: Dasal-Fikr, 1977), 3881; Mannan, Islamic Economy, 115-118.

${ }^{25}$ Pemberian yang bersifat individual ini biasanya disebut insentif, baik yang berupa piecework, komisi, curve maturity, merit raises, pay for knowledge compensation, non monetary incentive ataupun incentive executive.
} 


\section{Profit-sharing plans}

Profit-sharing plans adalah sistem membagi keuntungan perusahaan dengan para pekerja. Profit-sharing dipilih karena keuntungan tidak selalu berhubungan dengan performa pekerja. Sebuah resesi atau kompetisi baru bisa berpengaruh secara signifikan. Beberapa perusahaan kemudian mengantisipasinya dengan mengurangi insentif untuk kemudian mengalokasikannya pada pembagian profitpekerja. Ketika langkah reinforcement (penguatan) ini berjalan dengan baik, maka akan menimbulkan pengaruh yang dramatis pada organisasi, melahirkan kepercayaan baru dan memunculkan perasaan senasib-sepenanggungan di antara para pekerja dan menajemen. ${ }^{26}$

Dengan gainsharing system di atas, maka tidak ada alasan bagi buruh untuk malas bekerja, karena hasil yang akan mereka terima (deviden) bergantung pada produktivitas yang mereka hasilkan. Disamping itu, mereka juga masih menerima upah harian yang besaran dan regulasinya menggunakan model ijakah, yang secara teo ritik hampir sama dengan teori Marginal Productivity dan teori Bargaining.

Riset Werther menyebutkan bahwa sistem gainsharing mampu menumbuhkan perasaan senasib sehingga bisa meningkatkan komitmen, performa, produktivitas, dan kualitas kerja. Dia menyatakan bahwa $80 \%$ perusahaan di Amerika menggunakan sistem gainsharing sebagaimana yang telah dilakukan oleh Lincoln Electric. Dengan gainsharing, pengusaha telah membagi informasi finansial dan non finansial dengan pekerja lebih sering (65 persen) dibanding perusahaan tanpa gainsharing (37 persen). Selama tahun 1980 dan awal 1990, penggunaan gainsharing menjadi berlipat ganda. ${ }^{27}$

Di Indonesia, Bank Mandiri dan Bank BRI adalah contoh perusahaan yang menerapkan sistem tersebut. Hasilnya sangat fantastis. Dalam waktu dua tahun sejak pola tersebut diterapkan, return saham Bank Mandiri naik $119 \%$, sedangkan Bank BRI naik 234\%. ${ }^{28}$

Sampai di sini sesungguhnya masih ada masalah lain, yakni bagaimana menyiapkan basis kesadaran kultural dan struktural yang memungkinkan cita ideal tersebut menjadi sebuah kenyataan sosial-politik di negeri ini. Dalam konteks negara kebangsaan, norma tersebut harus dipahami sebagai bahan baku (raw material) seperti halnya hukum adat atau hukum hukum yang lain, yang bisa saja ditransformasikan menjadi hukum positif sejauh bisa disepakati/diterima oleh forum pengambil keputusan publik (parlemen) melalui cara dan prosedur yang demokratis.

Seharusnya disadari bahwa sesuci dan sekuat apapun, sebuah normativitas naqliyah sifatnya adalah lokal komunal. Daya takluk argumen itu hanya berlaku secara internal atas umat yang mengimaninya saja. Itu pun masih harus membereskan hambatan hambatan hermeunetik (tafsir) yang masih bisa berbeda antara satu orang (atau madhhab) dengan lainnya.

Untuk bisa menjadi bagian dari hukum publik, maka norma-norma tersebutharus memenuhi dua syarat. Pertama, syarat substansial yang menyangkut muatan normatif yang berorientasi pada kepentingan publik, bukan hanya kepentingan kelompok tertentu. Kedua, syarat prosedural, dalam

\footnotetext{
${ }^{26}$ William B Werther, Human Resources and Personal Management (New York: University of Miami, 1989), 373.

${ }^{27}$ Ibid., 365.

${ }^{28}$ Wawasan, 11 J uli 2005.
} 
arti bahwa norma tersebut dapat meyakinkan nalar publik untuk diterima melalui prosedur penetapan hukum secara demokratis yang juga disepakati oleh publik. Hukum atau norma apapun yang memenuhi kedua syarat tersebut berhak mengisi bangunan hukum positif dan perundang-undangan suatu negara. Tidak terkecuali hukum yang berbasis agama.

Bahkan untuk negara modern yang kini telah menjadi semakin represif, koruptif, eksploitatif, dan tidak peduli dengan nasib masyarakat lemah, kontribusi agama-agama dengan kekayaan nilainilai etik dan moralnya sangatlah diperlukan. Kita membutuhkan etika Islam dengan sentuhan nilai keadilannya, moral Kristen dengan basis kasihnya, $\mathrm{H}$ indu dengan semangat ahimsa (non violence)nya, dan Budha dengan etos kesederhanaannya.

\section{Penutup}

J auh sebelum Max Weber menulis The Protestant Ethic and The Spirit of Capitalism (19041905) yang menghubungkan agama dan etika kerja, dalam kasus Islam, hubungan itu justru yang mendorong kehadirannya. Karena itu, tidak berlebihan jika Islam diharapkan mampu berbicara banyak mengenai konsep perburuhan agar penanganan masalah ini tetap mengacu kepada fitrah kemanusiaan yang menjadi misi setiap agama.

Selama ini masih terdapat stereotip bahwa persoalan buruh sangat ditentukan oleh dua ekstrimitas sistem ekonomi, yaitu kapitalisme dan sosialisme. Sistem kapitalisme diasumsikan cenderung mengeksploitasi kaum buruh, sementara sosialisme cenderung bersikap sebaliknya, yaitu membela buruh. Mengingat dua ekstrimitas tersebutmempunyai plus-minus, pemerintah Indonesia kemudian mengadopsi konsep negara sejahtera (welfare state). Negara sejahtera berkeyakinan bahwa kesejahteraan individu merupakan sesuatu yang sangat penting dan tidak mungkin hanya tergantung dengan operasi pasar. Karena itu, negara harus melakukan intervensi untuk menjaga fungsi pasar secara sempurna dan memperbaiki ketidakadilan yang diciptakan kapitalisme laissez-faire.

Konsep negara sejahtera - yang menjadi payung kebijakan perburuhan - belum sepenuhnya sejalan dengan idealisme Islam. Sebab, dalam fungsinya yang sebatas regulator, pemerintah sulit menjamin kesejahteraan warganya karena ia tidak mempunyai keberpihakan yang jelas terhadap pemerataan keuntungan produksi. Hal ini, disadari atau tidak, pada gilirannya akan semakin memperkuat posisi kapital, memperlebar jurang kesenjangan, meningkatkan kekuasaan perusahaan, dan memberi kesempatan untuk 'menindas' orang atas nama efisiensi dan iklim usaha. Konsep ini akan membuat si kaya menjadi lebih kaya dan si miskin menjadi lebih miskin.

Tawaran Islam adalah mengembangkan konsep gainsharing system dengan mengkombinasikan shirkah 'inan-ijakah. Dengan konsep ini, seorang buruh mempunyai posisi yang relatif sama dengan majikan dalam hal keuntungan. Semakin tinggi laba yang diperoleh, maka dengan sendirinya upah mereka akan naik. Begitupun sebaliknya. J ika perusahaan mengalami kerugian, maka seorang buruh pun ikutmerasakan derita majikannya. Dengan cara ini, tidak ada alasan bagi buruh untuk malas bekerja, karena hasil yang akan mereka terima (deviden) bergantung pada produktivitas yang mereka hasilkan. Disamping itu, mereka juga masih menerima upah harian yang besaran dan regulasinya menggunakan model ijakah, yang secara teoritik hampir sama dengan teori Marginal Productivity dan teori Bargaining. 


\section{Daftar Rujukan}

al-Azhari> 'Abd Allah ibn Hijazi>ibn Ibrahim al-Shafi'i. H ashiyah al-Sharqawi>ala Tuhfat alTullab, vol.2. Beirut: Dasal-Ma'rifah, t.t.

Briggs, Asa. "The Walfare State in Historical Perspective", dalam Archives Europeenes de Sociologie, 1961.

Brinton, Crane. "Eglightenment", dalam Encyclopedia of Philosophy, vol 2. New York: Macmillan and the Free Press, 1967.

al-Buhuti>Mansłlisibn Yunus ibn Idris. Sharh Muntaha al-Iradat al-M usamma, vol. 2. Madinah: Maktabat al-Salafiyah, 1980.

Budiono. Tori Eknomi Mikro. Yogyakarta: BPFE, 1998.

Chapra, U mer. Islam dan Tantangan Ekonomi. J akarta: IIT, 2000.

al-Fanjari>Shawqi>H úquq al-'U mmal fiəal-Islam. Riyad: Rabităt al-'Alam al-Islami, t.t.

Gramsci, Antonio. "Ekonomi dan Korporasi Negara", dalam Catatan-catan Politik, ter. Gafna

Raiza. Surabaya: Pustaka Promethea, 2001.

Hitti, Philip K. History of The Arabs. London: The Macmillan Press Ltd., 1970.

Indaryani, Mamik, et al. Hasil Penelitian Penentuan Upah M inimal di Kabupaten Kudus J awa

tengah. Kudus: Kantor Tenaga Kerja dan Transmigrasi bekerjasama dengan Litbang UMK, 2002.

al-Isfihani> A bual-Faraj. Kitab al-Aghani>vol. 1. Beirut: Matha'at al-'Arabiyah, t.t.

Mannan, M.A. Islamic Economy: Theory and Practice. England: Edward Arnold Limited, 1993.

McEachern, William A. Ekonomi Mikro Pendekatan Kontemporer. J akarta: Thomson Learning, 2001.

Rahman, Fazlur. Islam and Modernity Transformation of an Intellectual Tradition. Chicago:

The University of Chicago Press, 1982.

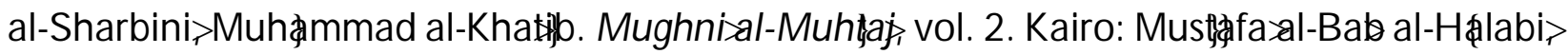
1985.

Setiadji, Bambang. Upah antar Buruh Industri di Indonesia. Surakarta: Muhammdiyyah

University Press, 2002.

Tempo interaktif, 19 J anuari 2005.

'U thman, Fakhr al-Din ibn 'Alkial-H dnafi>Tabyin al-H aqaiø, vol. 5. Kairo: Mat\}ba'at al-KubraalAmirizah, $1315 \mathrm{H}$.

Wawasan, 11 J uli 2005.

Werther, William B. Human Resources and Personal Management. New York: University of Miami, 1989.

Zaman, S.M. Hasanuz. Economic Foundation of an Economic State: The Early Experience. Leicester: The Islamic Foundation, 1991.

Zuhæyli>Wahbah. Al-Fiqh al-Islamii>wa Adillatuh, vol. 5. Damaskus: Dasal-Fikr, 1977. 